\title{
AN INVERTEBRATE ECOSYSTEM ENGINEER UNDER THE UMBRELLA OF SAGE-GROUSE CONSERVATION
}

\author{
Jason D. Carlisle 1,2 , David R. Stewart ${ }^{3}$, and Anna D. Chalfoun ${ }^{4}$
}

\begin{abstract}
Conservation practitioners often rely on areas designed to protect species of greatest conservation priority to also conserve co-occurring species (i.e., the umbrella species concept). The extent to which vertebrate species may serve as suitable umbrellas for invertebrate species, however, has rarely been explored. Sage-grouse (Centrocercus spp.) have high conservation priority throughout much of the rangelands of western North America and are considered an umbrella species through which the conservation of entire rangeland ecosystems can be accomplished. Harvester ants are ecosystem engineers and play important roles in the maintenance and function of rangeland ecosystems. We compared indices of the abundance of western harvester ants (Pogonomyrmex occidentalis) and Greater Sage-Grouse (Centrocercus urophasianus) at 72 sites in central Wyoming, USA, in 2012. The abundance of harvester ant mounds was best predicted by a regression model that included a combination of local habitat characteristics and the abundance of sage-grouse. When controlling for habitat-related factors, areas with higher abundances of sage-grouse pellets (an index of sage-grouse abundance and/or habitat use) had higher abundances of ant mounds than areas with lower abundances of sage-grouse pellets. The causal mechanism underlying this positive relationship between sage-grouse and ant mound abundance at the fine scale could be indirect (e.g., both species prefer similar environmental conditions) or direct (e.g., sage-grouse prefer areas with a high abundance of ant mounds because ants are an important prey item during certain life stages). We observed no relationship between a broad-scale index of breeding sage-grouse density and the abundance of ant mounds. We suspect that consideration of the nonbreeding habitat of sage-grouse and finer-scale measures of sagegrouse abundance are critical to the utility of sage-grouse as an umbrella species for the conservation of harvester ants and their important role in rangeland ecosystems.
\end{abstract}

RESUMEn.-Los expertos en la conservación a menudo se valen de las zonas diseñadas para la protección de las especies con mayor prioridad de conservación, para preservar también a otras especies co-existentes (es decir, el concepto de especie sombrilla). Sin embargo, pocas veces se investiga hasta qué punto las especies de vertebrados pueden servirle de especies sombrilla a las especies de invertebrados. El urogallo (Centrocercus spp.) tiene una alta prioridad de conservación en gran parte de los pastizales del oeste de América del Norte y se le considera una especie sombrilla, ya que a través de ella se pueden conservar ecosistemas de pastizales completos. Las hormigas cosechadoras, consideradas ingenieras de ecosistemas, desempeñan un importante papel en el mantenimiento y en la función de los ecosistemas de pastizales. En 2012, comparamos los índices de abundancia de las hormigas cosechadoras occidentales (Pogonomyrmex occidentalis) y del urogallo de las artemisas (Centrocercus urophasianus) en 72 puntos del área central de Wyoming, EE.UU. La cantidad de hormigueros de hormigas cosechadoras se predijo de mejor manera mediante un modelo de retroceso basado en la combinación de características locales del hábitat y de la abundancia de urogallos. Al determinar los factores relacionados al hábitat, se observaron, en las áreas con mayor cantidad de egagrópilas de urogallo (un índice de abundancia de urogallo y/o del uso del hábitat) una mayor cantidad de hormigueros, en comparación a las áreas con menor cantidad de egagrópilas de urogallo. El mecanismo causal que subyace a esta relación positiva entre el urogallo y la abundancia de hormigueros podría ser indirecto (e.g., ambas especies prefieren condiciones ambientales similares) o directo (e.g., los urogallos prefieren áreas con grandes cantidades de hormigueros porque las hormigas son un elemento de presa importante durante ciertas etapas de sus vidas). No observamos ninguna relación a gran escala entre el índice de densidad de reproducción de urogallos y la abundancia de hormigueros. Sospechamos que la consideración del hábitat no reproductivo del urogallo y de la abundancia del urogallo es fundamental para determinar la utilidad del urogallo como especie sombrilla en la conservación de las hormigas cosechadoras y de su papel tan importante en los ecosistemas de pastizales.

The umbrella species concept is a key idea in the theory and practice of conservation via surrogate species (Noss 1990, Caro 2010). The appeal of the concept lies in the hope that protecting the habitat of a species with large area requirements (the umbrella species) results in an indirect protection of many other species (Wilcox 1984, Noss 1990), providing a conceptual and logistical shortcut to reaching conservation goals (Simberloff 1998, Caro

1Wyoming Cooperative Fish and Wildlife Research Unit, Department of Zoology and Physiology, Program in Ecology, University of Wyoming, Department 3166, 1000 E. University Ave., Laramie, WY 82071.

${ }^{2}$ Present address: Western EcoSystems Technology, Inc., 200 S. 2nd St., Laramie, WY 82070. E-mail: jcarlisle@west-inc.com

${ }^{3}$ U.S. Fish and Wildlife Service, Division of Biological Sciences, Box 1306, Albuquerque, NM 87103.

${ }^{4}$ U.S. Geological Survey Wyoming Cooperative Fish and Wildlife Research Unit, Department of Zoology and Physiology, Program in Ecology, University of Wyoming, Department 3166, 1000 E. University Ave., Laramie, WY 82071. 
2010). The theoretical advantage of an umbrella species conservation strategy is the ability to conserve numerous sympatric species ancillary to the umbrella species, without extensive or specific consideration of each of these background species, thus streamlining and simplifying conservation efforts (Caro 2003, 2010). In practice, applications of the umbrella species concept can fall short by not meeting the conservation objectives set for co-occurring species of interest (Berger 1997, Andelman and Fagan 2000, Fleishman et al. 2001, Roberge and Angelstam 2004, Dunk et al. 2006). Moreover, some argue that the lax and unclear terminology used for surrogatespecies concepts can hamper the selection of suitable surrogates (Caro and O'Doherty 1999) or miscommunicate ecological concepts in nontechnical media (e.g., news articles; Barua 2011). Surrogate-species strategies (including umbrella species), however, have grown in popularity (Caro 2003, 2010), and such strategies are being adopted into nationwide efforts to manage wildlife and conserve ecosystems in the United States (USFWS 2015).

Following population declines and subsequent review for listing under the U.S. Endangered Species Act, the Greater SageGrouse (Centrocercus urophasianus; hereafter sage-grouse) has been the focus of much of the conservation efforts in western rangelands (Knick and Connelly 2011, USFWS 2013). The Greater Sage-Grouse was originally proposed as an umbrella species whose conservation could cover many taxonomic groups of the sagebrush-steppe ecosystem's biota (Rich and Altman 2001). There have been several studies investigating the umbrella role of sagegrouse in the conservation of other vertebrate animals (Rowland et al. 2006, Hanser and Knick 2011, Gamo et al. 2013, Copeland et al. 2014, Norvell et al. 2014, Carlisle 2017), but we know of no study to date that has examined the utility of sage-grouse as an umbrella species for conserving invertebrate taxa. The general efficacy of using vertebrate umbrella species as a surrogate for the conservation of invertebrate taxa has been questioned (Kerr 1997, Oliver et al. 1998, Simberloff 1998, Rubinoff 2001); however, because information on the distribution and abundances of invertebrate species is lacking, conservation practitioners often resort to surrogate approaches to invertebrate conservation (Oliver et al. 1998).
Many invertebrates play an important role in the stability of natural and agricultural systems (Allen-Wardell et al. 1998). In particular, the global ecological importance of ants (Hymenoptera: Formicidae) is becoming increasingly apparent. Ants inhabit virtually all terrestrial ecosystems, and while ants receive little conservation attention, they play important ecological roles and are among "the little things that run the world" (Wilson 1987). Ants maintain ecosystem processes (e.g., soil movement, nutrient cycling, carbon dynamics), provide ecosystem services (e.g., plant community regulation, seed dispersal and pollination, and biological control of pest species), and produce goods valued by people (e.g., food and biomedical products, biodiversity maintenance and agroecosystem management) (reviewed in Del Toro et al. 2012).

Mound-building ants, including those that build pebble mounds (Pogonomyrmex spp.) and thatched mounds (Formica spp.), are widely distributed across the sagebrushsteppe rangelands of western North America, where sage-grouse occur (Scott 1951, Hanser et al. 2011b). In western North America, rangelands-lands which are managed as a natural ecosystem and on which the indigenous vegetation is predominantly grasses, grass-like plants, forbs, or shrubs (see definition of rangelands in Society for Range Management 1999)—are often managed to provide forage and habitats for livestock and wildlife (Payne and Bryant 1994). The herbivorous and granivorous tendencies of rangeland ant species have historically been blamed for reducing rangeland forage availability and hampering agricultural crop production (Dean 1903, Sneva 1979, Knight 1994), in addition to damaging roads and otherwise being a nuisance to humans (Headlee and Dean 1908, Fritz and Vickers 1942). More recently, some rangeland ants have been recognized as ecosystem engineers (Dibner et al. 2015, Gosselin et al. 2016), and their valuable ecological role has become more clearly understood. The alterations rangeland ants make to their environment through herbivory, granivory, seed dispersal, and modification of the physical and chemical properties of the soil often have positive effects on the abundance, diversity, and fitness of plants (Beattie and Culver 1977, Rissing 1986, McKone 1989, Folgarait 1998), play an important role in rangeland disturbance 
regimes and succession (Knight 1994), and structure the broader biological community (Dibner et al. 2015, Gosselin et al. 2016). As such, ants enhance the capacity of the biotic community to support ecological processesan attribute of healthy rangelands (Pellant et al. 2005). If managers hope to protect the important components of the sagebrushsteppe ecosystem under the simplified sagegrouse umbrella of conservation actions, sage-grouse must be a good surrogate for rangeland ants.

Our objective was to identify whether sagegrouse abundance, a common conservation prioritization metric in rangelands of western North America, can predict the abundance of mounds of western harvester ants (Pogonomyrmex occidentalis, hereafter harvester ant). Harvester ants are not generally considered rare or in need of conservation action, but we chose to evaluate them because of the recognized role they play as ecosystem engineers important to the maintenance and function of rangeland ecosystems (Dibner et al. 2015, Gosselin et al. 2016). The axiom to "keep common species common" (e.g., Marra et al. 2015, Watson and Watson 2015) is founded upon the ideas that common species (excepting invasive or exotic species) often play valuable ecosystem roles and that reduced abundances of common species can cascade to affect other species (Hooper et al. 2005, Gaston 2010). The greater short-horned lizard (Phrynosoma hernandesi) may be one example of a species susceptible to changes in ant distribution or abundance. Ants are the primary prey of greater short-horned lizards (Stebbins 2003, Dibner 2015), and greater short-horned lizards are a species of state-level conservation concern thought to be experiencing range-wide population declines (Wyoming Game and Fish Department 2010).

\section{METHODS}

\section{Study Area and Design}

We conducted this study in sagebrushsteppe rangelands in central Wyoming, USA, centered on and within $60 \mathrm{~km}$ of the town of Jeffrey City $\left(42^{\circ} 29^{\prime} \mathrm{N}, 107^{\circ} 49^{\prime} \mathrm{W}\right.$; Fig. 1). Nearly $80 \%$ of the area was public land administered by the U.S. Bureau of Land Management, and primary land uses included livestock grazing and some energy development. The area was predominantly sagebrush steppe of varying structure and composition. Dominant shrub species included big sagebrush (Artemisia tridentata), greasewood (Sarcobatus vermiculatus), silver sagebrush (Artemisia cana), and black sagebrush (Artemisia nova), with some rabbitbrush (Chrysothamnus viscidiflorus and Ericameria nauseosa), spiny hopsage (Grayia spinosa), and saltbush (Atriplex sp.) also present at some sites. Elevation at the study sites ranged from $1715 \mathrm{~m}$ to $2220 \mathrm{~m}$.

We established 72 belt transects (i.e., survey locations) in 18 clusters of 4 belt transects each, following a clustered, stratified randomsampling scheme (Scheaffer et al. 2012). We used the 5 levels of a spatially explicit ranking of sage-grouse breeding densities (Doherty et al. 2010) as strata, and we drew a random sample of cluster centers (i.e., points) within each stratum. We restricted the sampling frame to include areas of public land accessible via 2-track dirt roads, excluding all areas within $1 \mathrm{~km}$ of oil/gas well locations or within $100 \mathrm{~m}$ of medium- or high-traffic roads (both paved and unpaved) to control for any potential confounding influence of anthropogenic disturbance. We allocated 18 clusters unequally across the 5 strata, with 3 clusters in the first stratum (the stratum with the lowest density of sage-grouse), 4 clusters each in the next 3 strata, and 3 clusters in the last stratum (the stratum with the highest density of sagegrouse). At each cluster, we established 4 parallel belt transects, each $500 \mathrm{~m}$ apart and oriented north-south (unless precluded by local topography or road presence, in which case transects were oriented west-east). Each belt transect was $500 \mathrm{~m}$ long and $8 \mathrm{~m}$ wide (0.4 ha).

\section{Data Collection}

We surveyed each belt transect once between 25 June and 4 July 2012, counting harvester ant mounds (Scott 1951) and sagegrouse fecal pellets (Boyce 1981, Schroeder and Vander Haegen 2006). Each transect was surveyed by 2 observers who walked side-byside approximately $4 \mathrm{~m}$ apart in a serpentine pattern along the belt transect, and each observer was responsible for sighting mounds and pellets within approximately $2 \mathrm{~m}$. Harvester ants create large, conical mounds (typically $20-50 \mathrm{~cm}$ tall with a basal diameter of 0.6-2 $\mathrm{m}$ and a surrounding clearing of 3-4 m 

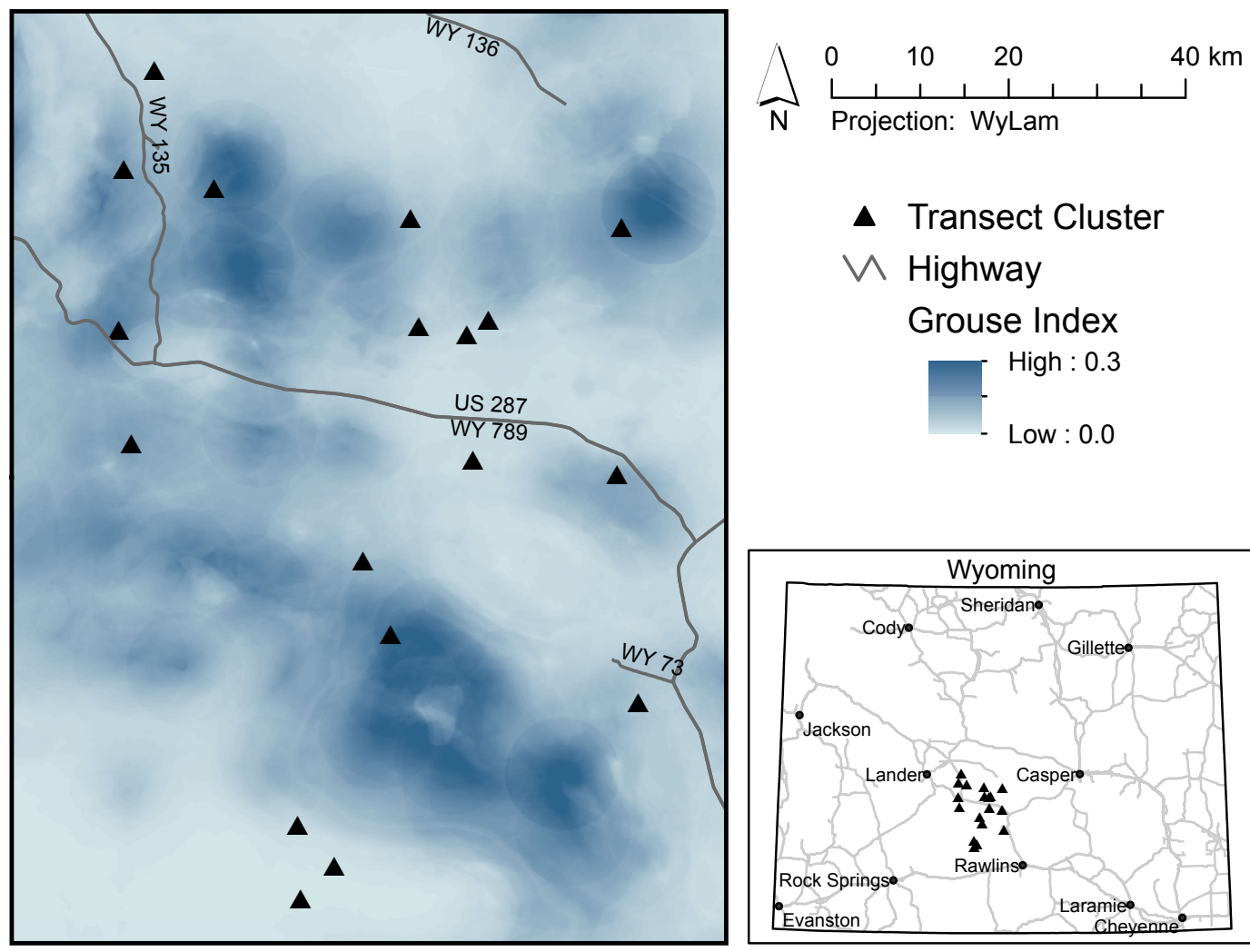

- Transect Cluster

\ Highway Grouse Index
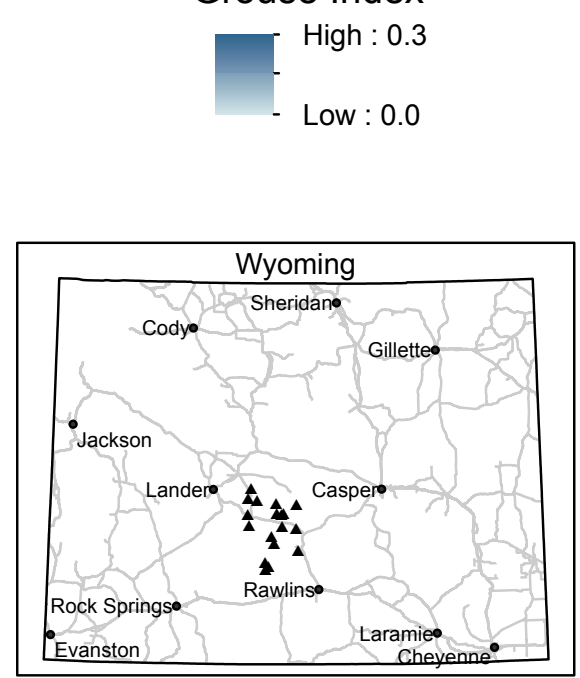

Fig. 1. Map of belt-transect clusters surveyed for western harvester ant mounds and Greater Sage-Grouse pellets in 2012 in central Wyoming, USA. Each cluster (black triangle) contained 4 parallel belt transects, each $8 \mathrm{~m}$ wide and $500 \mathrm{~m}$ long $(0.4 \mathrm{ha})$. Areas with darker shading had a higher index of Greater Sage-Grouse breeding population size (Doherty et al. 2016). Inset map shows study location relative to cities and highways.

in diameter; Dean 1903, Scott 1951), with the outer surface consisting of small ant-retrieved pebbles (Supplementary Material 1). Western harvester ants were the only harvester ant species in the study area, and their mounds were easily distinguished from sympatric thatching ants (Formica sp.) based on mound construction material (Wheeler and Wheeler 1988). Because of the large size of ant mounds and the narrow width of the search area, we assumed that the probability of detection was high and did not vary substantially across sites. The detection probability of sage-grouse pellets (Supplementary Material 2) is generally high within $2 \mathrm{~m}$ (Hanser et al. 2011a) and does not vary substantially, even when vegetation cover differs (Dahlgren et al. 2006). We included mounds with and without live ants visible on the surface, because surface activity can be a misleading indicator of mound inhabitance (Dean 1903). Therefore, our counts included mounds inhabited by active colonies and likely some mounds that were no longer inhabited. Harvester ant colonies can survive 15-30 years (Gordon and Kulig 1998, Ingram et al. 2013), and sage-grouse pellets can persist for up to 3 years (Boyce 1981); therefore, our mound and pellet counts represent cumulative measures of use across multiple years prior to data collection.

In addition to field surveys of sage-grouse pellets, we characterized the abundance of sage-grouse at each belt transect using a spatially explicit index of sage-grouse breeding population size produced by Doherty et al. (2016). The sage-grouse population index was a composite index that considered both habitat preferences and local abundances of breeding sage-grouse calculated for the Wyoming Basin (Sage-Grouse Management Zone II) at 120-m cell-size resolution. Population index values within the Wyoming Basin ranged from 0 to 
0.95, with higher values indicating higher densities of breeding sage-grouse (Doherty et al. 2016). Characteristics of the local habitat, including vegetation and soil, are known to be associated with the local abundance of harvester ant mounds (Kirkham and Fisser 1972, Sneva 1979). We characterized the habitat along each belt transect using spatially explicit data products that described vegetation (i.e., shrub and herbaceous plant cover; Homer et al. 2012) and soil properties (i.e., soil depth and sandiness; Natural Resources Conservation Service 2007, Keinath et al. 2010). Vegetation data sets were created at 30-m cell-size resolution using remote-sensing techniques (see Homer et al. 2012). We used soil data sets that were initially generated at coarser spatial resolutions (see Natural Resources Conservation Service 2007 for details) but then made available at 30-m cell-size resolution as part of a statewide effort to model the distributions of species of conservation concern (see Keinath et al. 2010).

We used the same method to generate a transect-level summary for each of the 5 variables that utilized spatial data sets (i.e., sagegrouse index, shrub cover, herbaceous cover, soil depth, and soil sandiness). We calculated a transect-level average as the mean cell value of all raster cells that were overlapped by the transect centerline. Spatial data handling and covariate attribution were conducted using the sp (Pebesma and Bivand 2005), rgdal (Bivand et al. 2017), rgeos (Bivand and Rundel 2017), and raster (Hijmans 2016) packages in Program R (R Core Team 2017).

\section{Statistical Analysis}

We used an information-theoretic model selection approach (Burnham and Anderson 2002) to compare the strength of evidence supporting model-based a priori hypotheses predicting the abundance of harvester ant mounds in a multiple-regression framework. We represented the umbrella hypothesis using a model in which the abundance of ant mounds was related to the abundance of an umbrella species (sage-grouse) characterized using 2 variables: one that described local counts of sage-grouse fecal pellets and one that described a spatially explicit index of sage-grouse breeding population density. We represented the habitat hypothesis using a model in which the abundance of ant mounds was related to the local habitat characteristics that were described using 4 habitat variables (shrub cover, herbaceous cover, soil depth, and soil sandiness) known to be associated with harvester ant abundance in other regions (Kirkham and Fisser 1972, Sneva 1979). We represented the combined habitat-umbrella hypothesis using a global model where the abundance of ant mounds was related to all 4 habitat variables and both sage-grouse variables, thereby controlling for local habitat characteristics in inferences about the umbrella species effect.

To quantify which model best predicted harvester ant abundance (or in other words, which hypothesis had the best support), we constructed regression models, a form of generalized linear model (GLM). Given count data, we typically assume $\left[N_{i} \mid \lambda_{i}\right] \sim \operatorname{Poisson}\left(\lambda_{i}\right)$, where $\lambda_{i}$ is the expected mean abundance of harvester ant mounds at site $i$, for $i \in I$. Since site-level abundance $\left(N_{i}\right)$ varies across sites, we specified our model to account for overdispersion by specifying the observation model to be marginal to a hierarchical element, $\epsilon_{i}$. The dispersion parameter of the hierarchical element is integrated into the likelihood of the Poisson process as a random effect to account for the variation among sites, resulting in a marginally distributed negative binomial mixture model by considering

$N_{i}\left|\epsilon_{i}, E_{i}, \lambda_{i} \sim \operatorname{Poisson}\left(\lambda_{i} \epsilon_{i}\right), \epsilon_{i}\right| \theta \sim \operatorname{gamma}(\theta, \theta)$, where $N_{i}=0,1,2,3, \ldots, N$ is the observed count of ant mounds at transect $i$. The resulting probability distribution marginal to $\epsilon_{i}$ is

$$
\begin{gathered}
P\left(N i=n_{i} \mid E_{i}, \lambda_{i}, \theta\right)= \\
\frac{\Gamma\left(n_{i}+\theta\right)}{\Gamma\left(n_{i}+1\right) \Gamma(\theta)}\left(\frac{\lambda_{i}}{\lambda_{i}+\theta}\right)^{n_{i}}\left(\frac{\theta}{n_{i}+\theta}\right)^{\theta},
\end{gathered}
$$

where $E\left(N_{i}\right)=\lambda_{i}$ and $V\left(N_{i}\right)=\lambda_{i}+\left(\lambda_{i}\right)^{2} / \theta$, where $\theta$ is the parameter of extra-Poisson variation in abundance among sites; and as $\theta \rightarrow \infty$, the distribution of $N_{i}$ converges to a Poisson process. The expected mean count $\lambda_{i}$ is expressed as a log-link function of predictor variables representing the model-based hypotheses as

$$
\log \left(\lambda_{i}\right)=\beta_{0}+\sum_{v=1}^{V} \beta_{v} x_{v, i}
$$

where $x_{v, i}$ are predictor variables $v=1, \ldots, V$ 
TABLE 1. Summary of predictor variables used to explain the abundance of western harvester ant mounds at 72 belt transects surveyed in 2012 in central Wyoming, USA. All values reported are before standardization, and Greater SageGrouse pellets reported are counts prior to $\log _{2}$ transformation. SD $=$ standard deviation, $C V=$ coefficient of variation.

\begin{tabular}{lrrrr}
\hline Predictor variable & Mean & SD & CV & Range \\
\hline Herbaceous cover $(\%)$ & 11.70 & 4.45 & 0.38 & $4.06-20.47$ \\
Shrub cover $(\%)$ & 11.31 & 4.63 & 0.41 & $5.00-23.47$ \\
Soil depth (cm) & 164.93 & 62.16 & 0.38 & $35.61-201.00$ \\
Soil sand component $(\%)$ & 58.43 & 8.75 & 0.15 & $34.30-68.50$ \\
Grouse index & 0.09 & 0.07 & 0.78 & $0.00-0.25$ \\
Grouse pellets (count) & 216.99 & 366.06 & $0-2103$ & 03 \\
\hline
\end{tabular}

measured at site $i$, and $\beta_{0}$ and $\beta_{v}$ are fixedeffect parameter coefficients, with

$$
\left(\begin{array}{l}
\beta_{0} \\
\beta_{v}
\end{array}\right) \sim \operatorname{MVN}\left(\left(\begin{array}{l}
\mu_{0} \\
\mu_{v}
\end{array}\right),\left(\begin{array}{cc}
\sigma_{0}^{2} & \rho \sigma_{0} \sigma_{v} \\
\rho \sigma_{0} \sigma_{v} & \sigma_{v}^{2}
\end{array}\right)\right)
$$

for $v=1, \ldots, V$, where $\mu=\left(\beta_{0}, \ldots, \beta_{v}\right)$ is a vector of length $l$, representing the mean of the parameter coefficients (i.e., intercept and slopes). The $j \times j$ covariance matrix is represented by the variance of the coefficients that is on the diagonal; the covariance is on the off-diagonals; and $\rho$ is the correlation between the coefficients. Because counts displayed some spatial autocorrelation (i.e., counts at adjacent transects were more similar than counts at distant transects), we explored a separate variance component of a random site effect that was incorporated into the models as an exchangeable term, $N \sim(0, \sigma)$ (Zuur et al. 2009; model structure described in Stewart et al. 2016), but we found that including this term produced no gain in model performance. Because counts of zero were common in our ant data (44\% of transects), we also explored the addition of a zero-inflation term (Martin et al. 2005, Arab et al. 2008; model structure described in Stewart et al. 2016) but found that the zero-inflation models assumed more false zeroes than were biologically likely, resulting in spurious parameter estimates.

Prior to model fitting, we log-transformed the pellet count data by first adding a constant of 1 and calculating the base-2 logarithm (Gotelli and Ellison 2004). All predictor variables were standardized with a mean of 0 and standard deviation of 1 to aid in convergence of parameter estimates (Kruschke 2014). We used the variance inflation factor (VIF) to assess the amount of multicollinearity among the standardized predictor variables, and we calculated VIFs using the car package (Fox and Weisberg 2011) in Program R (R Core Team 2017). To interpret the effects of each parame- ter on harvester ant mound abundance on the original, unstandardized scale of each predictor variable, we unstandardized parameter estimates using the expression $\beta_{v} * S D\left(x_{v}\right)$, then back-transformed the unstandardized parameter estimates using the inverse of the link to interpret effects on the count scale.

We implemented the hierarchical Bayesian negative binomial mixture models using JAGS software (Plummer 2015a) via the rjags (Plummer 2015b) and jagsUI (Kellner 2015) packages in Program R (R Core Team 2017), and we provide the JAGS syntax for specifying our model (Supplementary Material 3). We used Markov Chain Monte Carlo (MCMC) simulation to generate a posterior distribution and then used the sampled components as realizations $\left(\beta_{0}, \ldots, \beta_{v}\right)$ from the posterior to determine estimates of the posterior means and credible intervals for parameter estimates based on diffuse, noninformative priors. Candidate models were simulated using 3 parallel chains of 300,000 iterations with a burn-in period of the first 75,000 iterations and a thinning rate of 1 . We considered parameter estimates to have converged when MCMC chains were visually well mixed (Supplementary Material 4) and when the potential scale reduction factor $(\widehat{R})$ was $<1.10$ (Gelman and Rubin 1992, Gelman and Shirley 2011). Candidate models were ranked using the deviance information criterion (DIC; Spiegelhalter et al. 2002), an information-theoretic approach akin to the more familiar Akaike information criterion but specific to Bayesian models (Anderson 2008). The relative likelihood of each candidate model was determined by calculating model weights (Anderson 2008), and evidence of one model over another was expressed as $\triangle \mathrm{DIC}$ or by comparing model weights (Burnham and Anderson 2002). We assessed the discrepancy $(D(N))$ in model adequacy by measuring departures from the observed data $N_{i}$ and assumed model $N_{i}^{*}$ by 
TABLE 2. Model selection results comparing candidate hierarchical Bayesian models based on a priori hypotheses describing the abundance of western harvester ant mounds in relation to habitat and Greater Sage-Grouse-related variables in 2012 in central Wyoming, USA. DIC = deviance information criterion, $\triangle \mathrm{DIC}=$ difference in DIC values between the model and the top-ranked model in the set, $w=$ model weight.

\begin{tabular}{lcrc}
\hline Model & DIC & $\Delta$ DIC & $w$ \\
\hline Habitat-umbrella & 272.13 & 0.00 & 0.89 \\
Habitat & 276.32 & 4.19 & 0.11 \\
Umbrella & 288.97 & 16.84 & 0.00 \\
\hline
\end{tabular}

TABle 3. Parameter estimates from the top-ranked hierarchical Bayesian model describing the abundance of western harvester ant mounds in relation to habitat and Greater Sage-Grouse-related variables (the habitatumbrella hypothesis) in 2012 in central Wyoming, USA. Estimates and their 95\% Bayesian credible interval (BCI) are presented after being unstandardized and back-transformed for interpretation on the count scale. The appropriate unit scale for interpreting each parameter estimate is indicated. For example, for each incremental $1 \%$ increase in herbaceous cover, the abundance of mounds decreased by a relative $2 \%$. Because the count of Greater Sage-Grouse pellets was transformed prior to analysis using $\log _{2}$, each 1-unit increase in grouse pellets equated to a doubling of the pellet count.

\begin{tabular}{lccc}
\hline Variable & Units & Estimate & BCI \\
\hline Herbaceous cover & $1 \%$ & 0.98 & $0.91-1.06$ \\
Shrub cover & $1 \%$ & 0.62 & $0.50-0.74$ \\
Soil depth & $10 \mathrm{~cm}$ & 0.91 & $0.84-0.98$ \\
Soil sand component & $1 \%$ & 0.98 & $0.94-1.03$ \\
Grouse index & 0.1 units & 0.61 & $0.25-1.53$ \\
Grouse pellets $\left(\log _{2}\right)$ & Doubling & 1.22 & $1.10-1.35$ \\
\hline
\end{tabular}

calculating a Bayesian $P$ value for each candidate model, specifically:

$$
\begin{gathered}
p_{D}=P\left[D\left(N^{*}, \theta\right)>D(N, \theta) \mid N\right] \\
=\int P\left[D\left(N^{*}, \theta\right)>D(N, \theta) \mid \theta\right] p(\theta \mid N) d \theta .
\end{gathered}
$$

A Bayesian $P$ value near 0.5 indicates good model fit, and values close to 0 and 1 suggest lack of fit (e.g., overfitting) of the model (Gelman et al. 1995). Parameter estimates are presented as posterior means $\pm 95 \%$ Bayesian credible intervals, and the effect was considered equivocal of any parameter for which the Bayesian credible interval contained 0 .

\section{RESULTS}

We observed 340 harvester ant mounds, with mound density varying substantially across belt transects $(\bar{x}=11.81$, SD 14.36,

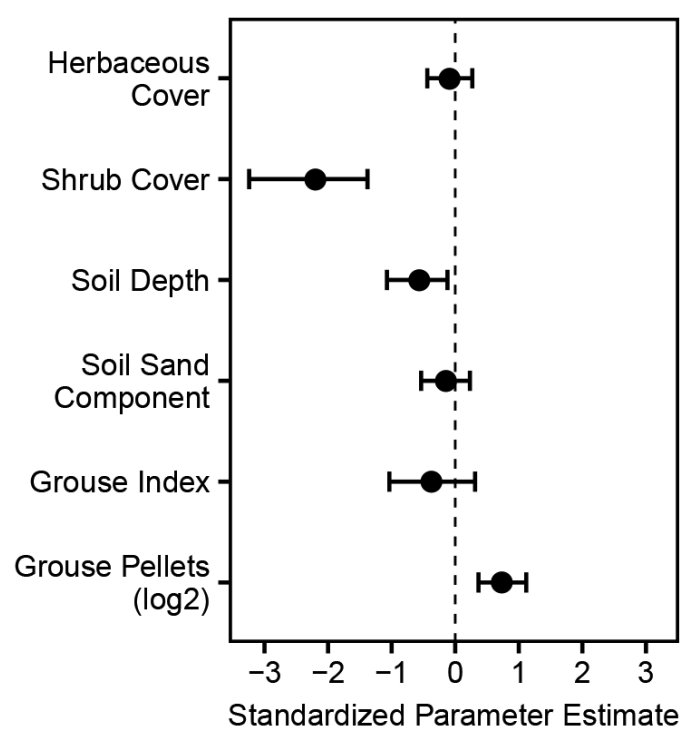

Fig. 2. Parameter estimates $( \pm 95 \%$ Bayesian credible intervals) from the top-ranked hierarchical Bayesian model relating habitat and Greater Sage-Grouse-related variables to the abundance of western harvester ant mounds in 2012 in central Wyoming, USA. All predictor variables were standardized to have a mean of 0 and standard deviation of 1 prior to model fitting.

range 0-50 mounds per hectare). Before transformation and standardization, the 4 measures of habitat characteristics were much less variable across belt transects than variables summarizing sage-grouse abundance (mean coefficient of variation $=0.33$ and 1.24, respectively; Table 1). Multicollinearity among predictor variables was weak (Kutner et al. 2004), with all VIF values $<2.25$. The abundance of harvester ant mounds was best predicted by variables describing habitat and the abundance of sage-grouse. The best overall model was the habitat-umbrella model, with $89 \%$ model weight — 8.1 times greater support than the second-ranked model (Table 2). The Bayesian $P$ value for the best model was 0.48 and ranged from 0.46 to 0.49 for the remaining candidate model set, indicating good model fit. All results presented are from parameters estimated in the habitat-umbrella model (Table 3).

Shrub cover was the predictor variable with the strongest association with harvester ant abundance (Fig. 2), in which the abundance of harvester ant mounds decreased by a relative $37.76 \%(25.79 \%-50.36 \%)$ for every incremental $1 \%$ increase in shrub cover (Fig. 3). 

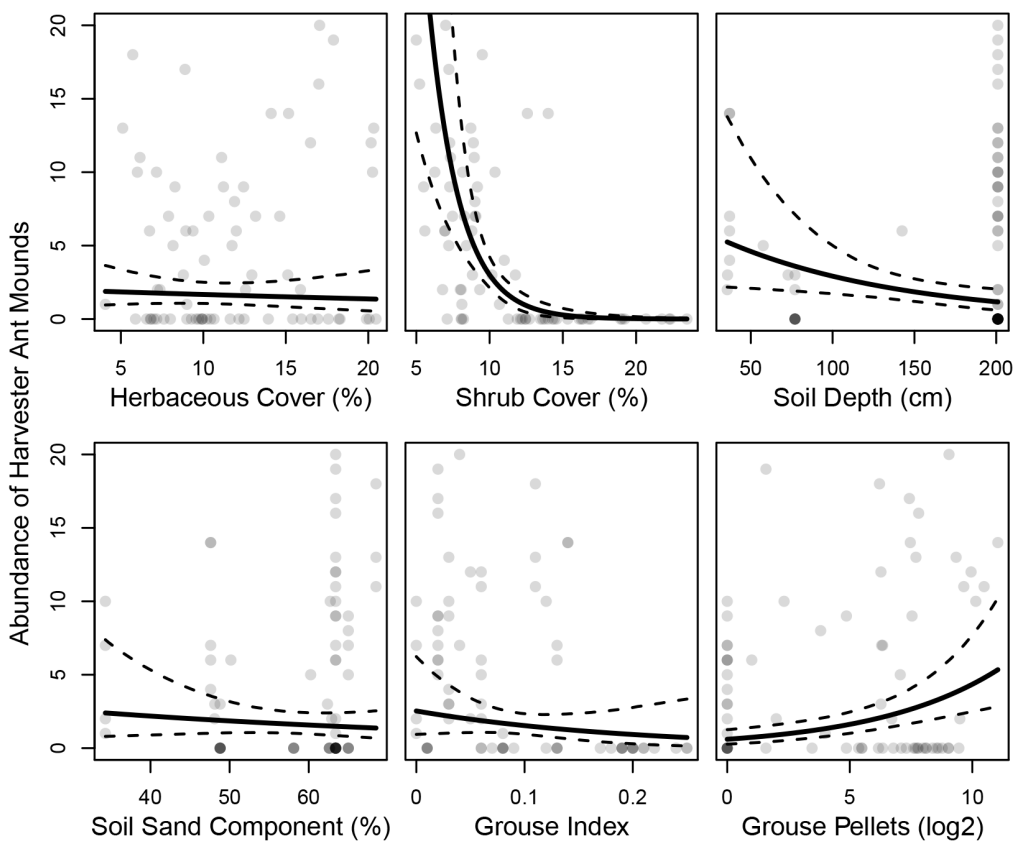

Fig. 3. Relationships between the abundance of western harvester ant mounds (per 0.4 ha) and predictor variables describing habitat and Greater Sage-Grouse in 2012 in central Wyoming, USA. Solid lines show estimated abundance from the top-ranked hierarchical Bayesian model, with dashed lines indicating $95 \%$ Bayesian credible intervals. Observed values are shown as transparent points to address overplotting; darker shades indicate multiple transects with the same values.

For every 1-unit increase in sage-grouse pellets (or because pellet counts were transformed prior to analysis using $\log _{2}$ for every doubling in the count of sage-grouse pellets), the abundance of harvester ant mounds increased by a relative $21.81 \%$ (10.34\%-35.02\%; Fig. 3). Conversely, mound abundance was negatively associated with soil depth. For every additional $10 \mathrm{~cm}$ of soil depth, the abundance of harvester ant mounds decreased by a relative $8.70 \%$ (1.96\%-15.86\%; Fig. 3). The 95\% Bayesian credible interval for all other standardized parameter estimates overlapped 0 , indicating that the associations between harvester ant mound abundance and all other predictor variables (herbaceous cover, soil sand component, and grouse index) were equivocal (Fig. 2, 3).

\section{Discussion}

We found strong support for the habitatumbrella hypothesis (8.1 times more support than for any alternative), meaning that vegetative and edaphic characteristics of the local habitat in combination with information regarding the abundance of an umbrella species
(Greater Sage-Grouse) were important determinants of the abundance of the mounds of harvester ants, an invertebrate ecosystem engineer. We are aware of only one other study (Martikainen et al. 1998) that used empirical evidence to document the successful use of a vertebrate umbrella species for the conservation of invertebrate taxa. In considering harvester ants, our study acknowledges the value that common species have within an ecosystem (Hooper et al. 2005, Gaston 2010) and broadens the taxonomic scope of the evaluations of the sage-grouse umbrella conducted to date. Although the abundance of harvester ants was not related to the broad-scale and spatially explicit breeding population index for the umbrella species, ant mounds were more abundant in areas with higher counts of the fecal pellets of the umbrella species, a local index of habitat use and/or abundance.

The densities of harvester ant mounds we observed were similar to those reported from elsewhere in the range of the species, including Oregon, Nevada, Utah, Kansas, and other sites in Wyoming (Headlee and Dean 1908, 
Scott 1951, Giezentanner and Clark 1974, Sneva 1979, Dibner et al. 2015). The densities of sage-grouse fecal pellets we observed were similar but slightly lower than pellet cluster densities observed in Utah (Dahlgren et al. 2006) and in another area of Wyoming (Boyce 1981). Values of the grouse index were low at our sites (Table 1) relative to other areas of Sage-Grouse Management Zone II, which covers portions of Wyoming, Colorado, Utah, Montana, and Idaho (where values ranged from 0 to 0.95 ; Doherty et al. 2016). Our findings agree with previous work showing that ant mound density was negatively related to shrub cover (Sneva 1979), but while previous studies suggested that soil texture and herbaceous cover were important (Kirkham and Fisser 1972, Sneva 1979), we found no relationship between these variables and mound density. Because tunnels and chambers within a harvester ant mound can extend 2-3 $\mathrm{m}$ below the soil surface (Scott 1951), we expected mounds to be associated with deeper soils; however, we found a negative relationship between soil depth and mound density. The soil data we used were generated at coarse spatial resolution, however, and we expect that fine-scale measures of soil depth and texture may reveal additional insight given the scale-dependent nature of ecological relationships (Wiens 1989, Levin 1992).

\section{Sage-Grouse and Ants}

Nearly a decade and a half ago, sage-grouse were first suggested as an umbrella species for protecting the sagebrush-steppe ecosystem, including its invertebrate and vertebrate animals, plants, and soils (Rich and Altman 2001). Since then, many have explored the idea of sage-grouse as an umbrella species for vertebrate taxa (Rowland et al. 2006, Hanser and Knick 2011, Gamo et al. 2013, Copeland et al. 2014, Norvell et al. 2014, Carlisle 2017), but this study is the first of which we are aware to assess the utility of sage-grouse for conserving invertebrate taxa. We acknowledge that both harvester ants and sage-grouse have broad geographic ranges; therefore, our results from central Wyoming may not be indicative of range-wide associations between these species. However, our results suggest the potential for harvester ants to be covered under the umbrella of sage-grouse conservation, with some caveats. For instance, broad-scale conservation planning efforts for sage-grouse often revolve around range-wide indices of breeding population density (Doherty et al. 2010, 2016), and we found no relationship between such an index and harvester ant mound abundance. Harvester ant mound abundance was higher, however, in areas with higher abundance of sage-grouse fecal pellets.

We suggest 3 possible explanations for the disparity between the effects of the 2 sagegrouse variables, but due to the observational nature of our study we were unable to identify the causal mechanisms underlying the observed relationships. First, sagebrush cover and seasonal habitat preferences of sage-grouse could explain the inconsistency. The sage-grouse index and pellet count data were weakly and positively correlated (Pearson's correlation coefficient $=0.35$ ), but the difference in what they represented biologically may explain why their correlative association with the abundance of harvester ant mounds was not consistent. For example, the sage-grouse index we used identified areas of high sagegrouse abundance during the breeding season. Breeding habitat for sage-grouse includes habitats used during lekking, nesting, and early brood-rearing, and productive sage-grouse breeding habitat generally has $15 \%-25 \%$ sagebrush cover (Connelly et al. 2000). We found shrub cover to be the most influential predictor of the abundance of harvester ant mounds (Fig. 2) and observed no harvester ant mounds at sites with $\geq 15 \%$ shrub cover (Fig. 3). In contrast, because sage-grouse fecal pellets can persist for multiple years (Boyce 1981, Stringham 2010), the sage-grouse pellet counts we observed likely represented habitat used by sage-grouse during the breeding and nonbreeding (i.e., late brood-rearing and winter) seasons. Areas used by sage-grouse during nonbreeding seasons tend to include sites with $<15 \%$ sagebrush cover (Connelly et al. 2000 ), and all harvester ant mounds in our study were located at sites with $<15 \%$ shrub cover (Fig. 3). Therefore, one explanation for the patterns we observed could be that harvester ant mounds are more abundant in the nonbreeding habitat than in the breeding habitat of sage-grouse. If this is the case, the prioritization and protection of nonbreeding (i.e., late brood-rearing and winter) habitat of sage-grouse will be critical for encompassing harvester ants (and the services they provide 
to healthy rangelands) under the umbrella of sage-grouse conservation.

Sage-grouse food preferences offer an alternative explanation for the association between harvester ants and sage-grouse pellet counts in our study. Invertebrates, including ants, make up a substantial portion of sagegrouse diets during certain life stages. Insects are essential to the growth and survival of sage-grouse chicks (Johnson and Boyce 1990), and insects dominate the diet of juveniles during the first few weeks of life (Klebenow and Gray 1968, Peterson 1970, Dahlgren et al. 2015). Adults feed primarily on forbs and sagebrush, but include insects in their diet during the spring and summer months (Dahlgren et al. 2015, Dumroese et al. 2015). If sage-grouse select habitats with abundant ant mounds during brood-rearing life stages, such a preference could manifest in a positive relationship between mound density and sagegrouse pellet abundance.

Lastly, male sage-grouse have been observed strutting from the tops of harvester ant mounds, potentially gaining greater visibility from the elevated height (Giezentanner and Clark 1974). Preference for ant mounds as strutting locations could explain the increase in sage-grouse pellets in areas with high mound density; however, strutting occurs on spatially distinct leks, and leks occupy only a small fraction of the landscape. It is unlikely that a significant portion of our belt transects overlapped leks; therefore, it is doubtful that the pattern we observed was due to lekking males preferring ant mounds for strutting. In summary, our results should be interpreted with consideration of multiple seasonal habitats and multiple scales of habitat selection.

We acknowledge that our findings for harvester ants in central Wyoming are likely not applicable to harvester ants throughout their range, nor universal to all invertebrates, especially those more limited in range or habitat preferences. The umbrella of sage-grouse conservation, however, has been posited to cover the broad biota of the sagebrush-steppe ecosystem (e.g., plants, invertebrates, cryptogramic crusts, and soil-dwelling organisms; Rich and Altman 2001), but few assessments of the validity of this assumption have been conducted. We encourage others to explore the effects of sage-grouse conservation on diverse taxa within the sagebrush-steppe ecosystem, not just vertebrate animals or species of immediate conservation concern. Multiyear studies that include reliable methods for aging sage-grouse pellets or ant mounds may have greater ability to detect relationships between sage-grouse, harvester ants, and temporal variation in habitat conditions. As spatial scale is an important consideration in ecology and conservation (du Toit 2010), we also recommend studies at finer and broader spatial scales to explore the consistency of the umbrella effect across scales relevant to organisms of the sagebrush steppe.

Despite popularity within the theory and practice of conservation biology, surrogatespecies approaches suffer from a casual and evolving terminology (Caro and O'Doherty 1999, Caro 2010, Barua 2011). This lax lexicon may be unavoidable given that a single surrogate species often fulfills multiple roles; for example, the Northern Spotted Owl (Strix occidentalis caurina) has been characterized as both a flagship and umbrella species for old-growth forests in the northwestern United States (Caro 2010). Likewise, whereas Greater Sage-Grouse are often touted as an umbrella species, their usage in practice often overlaps with the concept of indicator species, especially as indicators of biodiversity for reserve selection (Caro 2010). We maintained the umbrella-species framing of sage-grouse in our work for consistency with the growing literature exploring the utility of sage-grouse as a surrogate for other taxonomic groups.

\section{Conservation Implications}

Conservation actions in sagebrush-steppe ecosystems are likely to focus on sage-grouse into the foreseeable future. Harvester ants are ecosystem engineers that play important functional roles within these rangeland ecosystems. Our findings suggest that, at least in central Wyoming, the conservation prioritization of areas where sage-grouse are abundant is likely to coincide with areas with high abundance of harvester ant colonies, as long as the nonbreeding habitats of sage-grouse are considered and finer-scale measures of sagegrouse abundance are employed in the prioritization scheme. Our results support the general idea that sage-grouse could serve as an umbrella species for the conservation of the broader sagebrush-steppe ecosystem, and our novel contribution is to show this umbrella 
relationship between sage-grouse and an invertebrate species in a portion of their shared geographic range. Ants are highly responsive to human impacts, such as land use change, pollution, invasive species, and climate change (Folgarait 1998). These threats are some of the same faced by sage-grouse (Connelly et al. 2011); therefore, actions undertaken to ameliorate threats to sage-grouse have the potential to indirectly benefit rangeland ant populations.

\section{Supplementary Material}

Four online-only supplementary files accompany this article (scholarsarchive.byu.edu/wnan/ vol77/iss4/5).

Supplementary Material 1. Photographs of a western harvester ant mound and mound entrance near Jeffrey City, Wyoming, USA. Photos by Jason D. Carlisle.

Supplementary Material 2. Photograph of a cluster of Greater Sage-Grouse fecal pellets near Buffalo, Wyoming, USA. Photo by Jason D. Carlisle.

Supplementary Material 3. JAGS syntax for top-ranked negative binomial regression model relating habitat and Greater Sage-Grouse-related variables to the abundance of western harvester ant mounds in central Wyoming, USA.

Supplementary Material 4. Traceplots of MCMC chains and density plots of posterior probability distributions from the top-ranked hierarchical Bayesian model relating habitat and Greater Sage-Grouse-related variables to the abundance of western harvester ant mounds in central Wyoming, USA.

\section{ACKNOWLEDGMENTS}

This research was conducted as part of a larger study funded by the Wyoming Game and Fish Department and Wyoming SageGrouse Local Working Groups. J.D. Carlisle was additionally supported by a grant from the National Institute of General Medical Sciences (P20GM103432) from the National Institutes of Health. We thank A.M. Davis, D.P. Harvey, C.M. Laughlin, and S.E. Trapp for assistance in conducting field surveys and M.D. Andersen for assistance in acquiring soil data. This study and manuscript were improved by thoughtful comments from members of the Chalfoun lab group, namely J.P. Ceradini and L.E. Hall. We thank the associate editor and several anonymous reviewers for suggestions that improved this article.
The findings and conclusions in this article are those of the authors and do not necessarily represent the views of the U.S. Fish and Wildlife Service. Any use of trade, firm, or product names is for descriptive purposes only and does not imply endorsement by the U.S. Government.

\section{Literature Cited}

Allen-Wardell, G., P. Bernhardt, R. Bitner, A. Burquez, S. Buchmann, J. Cane, P.A. Cox, V. Dalton, P. Feinsinger, M. Ingram, et al. 1998. The potential consequences of pollinator declines on the conservation of biodiversity and stability of food crop yields. Conservation Biology 12:8-17.

Andelman, S.J., And W.F. Fagan. 2000. Umbrellas and flagships: efficient conservation surrogates or expensive mistakes? Proceedings of the National Academy of Sciences of the United States of America 97: $5954-5959$.

Anderson, D.R. 2008. Model based inference in the life sciences. Springer, New York, NY.

Arab, A., M.L. Wildhaber, C.K. Wikle, and C.N. GenTRY. 2008. Zero-inflated modeling of fish catch per unit area resulting from multiple gears: application to channel catfish and shovelnose sturgeon in the Missouri River. North American Journal of Fisheries Management 28:1044-1058.

BARUA, M. 2011. Mobilizing metaphors: the popular use of keystone, flagship and umbrella species concepts. Biodiversity and Conservation 20:1427-1440.

Beattie, A.J., And D.C. Culver. 1977. Effects of the mound nests of the ant, Formica obscuripes, on the surrounding vegetation. American Midland Naturalist 97:390-399.

Berger, J. 1997. Population constraints associated with the use of black rhinos as an umbrella species for desert herbivores. Conservation Biology 11:69-78.

Bivand, R.S., T. KeitT, and B. Rowlingson. 2017. rgdal: bindings for the Geospatial Data Abstraction Library. R package version 1.1-9. https://CRAN .R-project.org $/$ package $=$ rgdal

BIVAND, R.S., AND C.W. RundeL. 2017. rgeos: interface to Geometry Engine - Open Source (GEOS). R package version 0.3-19. https://CRAN.R-project.org/ package $=$ rgeos

Boyce, M.S. 1981. Robust canonical correlation of sage grouse habitat. Pages 152-159 in D. Capen, editor, The use of multivariate statistics in studies of wildlife habitat. USDA Forest Service General Technical Report RM-87, Fort Collins, CO.

Burnham, K.P., and D.R. Anderson. 2002. Model selection and multimodel inference: a practical information-theoretic approach. 2nd edition. SpringerVerlag, New York, NY.

Carlisle, J.D. 2017. The effect of sage-grouse conservation on wildlife species of concern: implications for the umbrella species concept. Dissertation, University of Wyoming, Laramie, WY.

Caro, T.M. 2003. Umbrella species: critique and lessons from East Africa. Animal Conservation 6:171-181.

Caro, T.M. 2010. Conservation by proxy: indicator, umbrella, keystone, flagship, and other surrogate species. Island Press, Washington, DC. 
Caro, T.M., and G. O’Doherty. 1999. On the use of surrogate species in conservation biology. Conservation Biology 13:805-814.

Connelly, J.W., S.T. Knick, C.E. Braun, W.L. Baker, E.A. Beever, T.J. Christiansen, K.E. Doherty, E.O. Garton, S.E. Hanser, D.H. Johnson, et aL. 2011. Conservation of Greater Sage-Grouse: a synthesis of current trends and future management. Pages 549563 in S.T. Knick and J.W. Connelly, editors, Greater Sage-Grouse: ecology and conservation of a landscape species and its habitats. Studies in Avian Biology 38. University of California Press, Berkeley, CA.

Connelly, J.W., M.A. Schroeder, A.R. SAnds, and C.E Braun. 2000. Guidelines to manage sage grouse populations and their habitats. Wildlife Society Bulletin 28:967-985.

Copeland, H.E., H. Sawyer, K.L. Monteith, D.E. Naugle, A. Pocewicz, N. Graf, and M.J. Kauffman. 2014. Conserving migratory mule deer through the umbrella of sage-grouse. Ecosphere 5:art117.

Dahlgren, D.K., R. Chi, and T.A. Messmer. 2006. Greater Sage-Grouse response to sagebrush management in Utah. Wildlife Society Bulletin 34:975-985.

Dahlgren, D.K., E.T. Thacker, and T.A. Messmer. 2015. What does a sage-grouse eat? Utah State University Extension, Logan, UT.

DEAn, G.A. 1903. The mound-building prairie ant (Pogonomyrmex occidentalis). Transactions of the Kansas Academy of Science 19:164-170.

Del Toro, I., R.R. Ribbons, and S.L. Pelini. 2012. The little things that run the world revisited: a review of ant-mediated ecosystem services and disservices (Hymenoptera: Formicidae). Myrmecological News 17:133-146.

DibnER, R.R. 2015. Ecological patterns vary across spatial scales for horned lizards and ants. Doctoral dissertation, University of Wyoming, Laramie, WY.

Dibner, R.R., D.F. DoAK, AND E.M. LOMbardi. 2015. An ecological engineer maintains consistent spatial patterning, with implications for community-wide effects. Ecosphere 6:art151.

Doherty, K.E., J.S. Evans, P.S. Coates, L.M. Juliusson, AND B.C. FEDY. 2016. Importance of regional variation in conservation planning: a rangewide example of the Greater Sage-Grouse. Ecosphere 7:e01462

Doherty, K.E., J.D. Tack, J.S. Evans, and D.E. Naugle. 2010. Mapping breeding densities of Greater SageGrouse: a tool for range-wide conservation planning. BLM completion report: interagency agreement \#L10PG00911.

Dumroese, R.K., T. Luna, B.A. Richardson, F.F. Kilkenny, AND J.B. RunYon. 2015. Conserving and restoring habitat for Greater Sage-Grouse and other sagebrushobligate wildlife: the crucial link of forbs and sagebrush diversity. Native Plants Journal 16:276-299.

Dunk, J.R., W.J. Zielinski, and H.H. Welsh Jr. 2006. Evaluating reserves for species richness and representation in northern California. Diversity and Distributions 12:434-442.

Du ToIT, J.T. 2010. Considerations of scale in biodiversity conservation. Animal Conservation 13:229-236.

Fleishman, E., R.B. Blair, and D.D. Murphy. 2001. Empirical validation of a method for umbrella species selection. Ecological Applications 11:1489-1501.

Folgarait, P.J. 1998. Ant biodiversity and its relationship to ecosystem functioning: a review. Biodiversity and Conservation 7:1221-1244.
Fox, J., AND S. WeIsBerg. 2011. An R companion to applied regression. 2nd edition. Sage, Thousand Oaks, CA.

Fritz, R.F., AND W.A. Vickers. 1942. Damage to highways by the mound-building prairie ant. Journal of Economic Entomology 35:725-727.

Gamo, R.S., J.D. Carlisle, J.L. Beck, J.A.C. Bernard, AND M.E. Herget. 2013. Greater Sage-Grouse in Wyoming: an umbrella species for sagebrush dependent wildlife. Wildlife Professional 7:56-59.

Gaston, K.J. 2010. Valuing common species. Science 327: $154-155$.

Gelman, A., J.B. Carlin, H.S. Stern, and D.B. Rubin. 1995. Bayesian data analysis. Wiley, New York, NY.

Gelman, A., AND D.B. Rubin. 1992. Inference from iterative simulation using multiple sequences. Statistical Science 7:457-472.

Gelman, A., AND K. Shirley. 2011. Inference from simulations and monitoring convergence. Pages 163-174 in S. Brooks, A. Gelman, G.L. Jones, and X.-L. Meng, editors, Handbook of Markov Chain Monte Carlo. Chapman and Hall, Boca Raton, FL.

Giezentanner, K.I., and W.H. Clark. 1974. The use of western harvester ant mounds as strutting locations by sage grouse. Condor 76:218-219.

Gordon, D.M., AND A. Kulig. 1998. The effect of neighbours on the mortality of harvester ant colonies. Journal of Animal Ecology 67:141-148.

Gosselin, E.N., J.D. Holbrook, K. Huggler, E. Brown, K.T. Vierling, R.S. ArKLe, and D.S. Pilliod. 2016. Ecosystem engineering of harvester ants: effects on vegetation in a sagebrush-steppe ecosystem. Western North American Naturalist 76:82-89.

Gotelli, N.J., AND A.M. Ellison. 2004. A primer of ecological statistics. 1st edition. Sinauer Associates, Inc., Sunderland, MA.

Hanser, S.E., C.L. Aldridge, M. Leu, M.M. Rowland, S.E. Nielsen, and S.T. Knick. 2011a. Greater SageGrouse: general use and roost site occurrence with pellet counts as a measure of relative abundance. Pages 112-140 in S.E. Hanser, M. Leu, S.T. Knick, and C.L. Aldridge, editors, Sagebrush ecosystem conservation and management: ecoregional assessment tools and models for the Wyoming Basins. Allen Press, Lawrence, KS.

Hanser, S.E., and S.T. KNICK. 2011. Greater SageGrouse as an umbrella species for shrubland passerine birds: a multiscale assessment. Pages 473-487 in S.T. Knick and J.W. Connelly, editors, Greater SageGrouse: ecology and conservation of a landscape species and its habitats. Studies in Avian Biology 38. University of California Press, Berkeley, CA.

Hanser, S.E., M. Leu, C.L. Aldridge, S.E. Nielsen, M.M. Rowland, and S.T. KNICK. 2011b. Occurrence and abundance of ants, reptiles, and mammals. Pages 221-314 in S.E. Hanser, M. Leu, S.T. Knick, and C.L. Aldridge, editors, Sagebrush ecosystem conservation and management: ecoregional assessment tools and models for the Wyoming Basins. Allen Press, Lawrence, KS.

Headlee, T.J., and G.A. Dean. 1908. The mound-building prairie ant. Kansas State Agricultural College Bulletin 154. Topeka, KS.

Hijmans, R.J. 2016. raster: geographic data analysis and modeling. $\mathrm{R}$ package version $2.5-2$. https://CRAN .R-project.org $/$ package $=$ raster

Homer, C.G., C.L. Aldridge, D.K. Meyer, and S.J. SCHELL. 2012. Multi-scale remote sensing sagebrush 
characterization with regression trees over Wyoming, USA: laying a foundation for monitoring. International Journal of Applied Earth Observation and Geoinformation 14:233-244.

Hooper, D.U., F.S. Chapin III, J.J. Ewel, A. Hector, P. Inchausti, S. LavoreL, J.H. LaWton, D.M. Lodge, M. LOREAU, S. NAEEM, ET AL. 2005. Effects of biodiversity on ecosystem functioning: a consensus of current knowledge. Ecological Monographs 75: $3-35$.

Ingram, K.K., A. Pilko, J. Heer, and D.M. Gordon. 2013. Colony life history and lifetime reproductive success of red harvester ant colonies. Journal of Animal Ecology 82:540-550.

Johnson, G.D., And M.S. Boyce. 1990. Feeding trials with insects in the diet of sage grouse chicks. Journal of Wildlife Management 54:89-91.

Keinath, D.A., M.D. Andersen, and G.P. Beauvais. 2010. Range and modeled distribution of Wyoming's species of greatest conservation need. Report prepared by the Wyoming Natural Diversity Database, Laramie, WY, for the Wyoming Game and Fish Department, Cheyenne, WY, and the U.S. Geological Survey, Fort Collins, CO.

KelLneR, K.F. 2015. jagsUI: a wrapper around 'rjags' to streamline 'JAGS' analyses. R package version 1.4.2. https://CRAN.R-project.org/package= jagsUI

KerR, J.T. 1997. Species richness, endemism, and the choice of areas for conservation. Conservation Biology 11:1094-1100.

Kirkham, D.R., AND H.G. Fisser. 1972. Rangeland relations and harvester ants in northcentral Wyoming. Journal of Range Management 25:55-60.

KLebenow, D.A., AND G.M. GRaY. 1968. Food habits of juvenile sage grouse. Journal of Range Management 21:80-83.

Knick, S.T., and J.W. Connelly, editors. 2011. Greater Sage-Grouse: ecology and conservation of a landscape species and its habitats. Studies in Avian Biology 38. University of California Press, Berkeley, CA.

KNIGHT, D.H. 1994. Mountains and plains: the ecology of Wyoming landscapes. 1st edition. Yale University Press, New Haven, CT.

Kruschke, J.K. 2014. Doing Bayesian data analysis: a tutorial with R, JAGS, and Stan. 2nd edition. Academic Press, Amsterdam.

Kutner, M.H., C.J. Nachtsheim, and J. Neter. 2004. Applied linear regression models. 4th edition. McGraw-Hill, New York, NY.

LEVIN, S.A. 1992. The problem of pattern and scale in ecology. Ecology 73:1943-1967.

Marra, P.P., E.B. Cohen, S.R. Loss, J.E. Rutter, And C.M. TonRa. 2015. A call for full annual cycle research in animal ecology. Biology Letters 11: 2015.0552

Martikainen, P., L. Kaila, and Y. Haila. 1998. Threatened beetles in White-backed Woodpecker habitats. Conservation Biology 12:293-301.

Martin, T.G., B.A. Wintle, J.R. Rhodes, P.M. Kuhnert, S.A. Field, S.J. Low-Choy, A.J. Tyre, and H.P. Possingham. 2005. Zero tolerance ecology: improving ecological inference by modelling the source of zero observations. Ecology Letters 8:1235-1246.

McKone, M.J. 1989. Intraspecific variation in pollen yield in bromegrass (Poaceae: Bromus). American Journal of Botany 76:231.
Natural Resources Conservation Service. 2007. Soil Survey Staff, NRCS, United States Department of Agriculture. Web Soil Survey. [Accessed 22 October 2007]. http://websoilsurvey.nrcs.usda.gov

Norvell, R.E., T.C. Edwards, and F.P. Howe. 2014. Habitat management for surrogate species has mixed effects on non-target species in the sagebrush steppe. Journal of Wildlife Management 78:456-462.

Noss, R.F. 1990. Indicators for monitoring biodiversity: a hierarchical approach. Conservation Biology 4: 355-364.

Oliver, I., A.J. Beattie, and A. York. 1998. Spatial fidelity of plant, vertebrate, and invertebrate assemblages in multiple-use forest in eastern Australia. Conservation Biology 12:822-835.

Payne, N.F., and F.C. BRYant. 1994. Techniques for wildlife habitat management of uplands. McGraw Hill, Inc., New York, NY.

Pebesma, E.J., and R.S. Bivand. 2005. Classes and methods for spatial data in R. R News 5:9-13.

Pellant, M., P. Shaver, D.A. Pyke, and J.E. Herrick. 2005. Interpreting indicators of rangeland health. U.S. Department of the Interior, Bureau of Land Management, Technical Reference 1734-6. Denver, CO.

Peterson, J.G. 1970. The food habits and summer distribution of juvenile sage grouse in central Montana. Journal of Wildlife Management 34:147-155.

Plummer, M. 2015a. JAGS: just another Gibbs sampler. Version 4.0.0. http://mcmc-jags.sourceforge.net

Plummer, M. 2015b. rjags: Bayesian graphical models using MCMC. R package version 4-6. https:// CRAN.R-project.org/package $=$ rjags

R Core Team. 2017. R: a language and environment for statistical computing. Version 3.3.0. R Foundation for Statistical Computing, Vienna, Austria. https:// www.R-project.org

Rich, T.D., and B. Altman. 2001. Under the sage-grouse umbrella. Bird Conservation 14:10.

Rissing, S.W. 1986. Indirect effects of granivory by harvester ants: plant species composition and reproductive increase near ant nests. Oecologia 68:231-234.

Roberge, J.-M., AND P. Angelstam. 2004. Usefulness of the umbrella species concept as a conservation tool. Conservation Biology 18:76-85.

Rowland, M.M., M.J. Wisdom, L.H. Suring, and C.W. MeInKE. 2006. Greater Sage-Grouse as an umbrella species for sagebrush-associated vertebrates. Biological Conservation 129:323-335.

RubinofF, D. 2001. Evaluating the California Gnatcatcher as an umbrella species for conservation of southern California coastal sage scrub. Conservation Biology 15:1374-1383.

Scheaffer, R.L., W. Mendenhall III, R.L. OtT, and K.G. Gerow. 2012. Elementary survey sampling. 7th edition. Cengage Learning, Boston, MA.

Schroeder, M.A., and W.M. Vander Haegen. 2006. Use of Conservation Reserve Program fields by Greater Sage-Grouse and other shrubsteppe-associated wildlife in Washington State. Washington Department of Fish and Wildlife, Olympia, WA.

ScotT, H.W. 1951. The geological work of the moundbuilding ants in western United States. Journal of Geology 59:173-175.

SimberlofF, D. 1998. Flagships, umbrellas, and keystones: is single-species management passé in the landscape era? Biological Conservation 83:247-257. 
SNEVA, F.A. 1979. The western harvester ants: their density and hill size in relation to herbaceous productivity and big sagebrush cover. Journal of Range Management 32:46-47.

Society for Range Management. 1999. A glossary of terms used in range management. Society for Range Management. Denver, CO.

Spiegelhalter, D.J., N.G. Best, B.P. Carlin, and A. van DER LINDE. 2002. Bayesian measures of model complexity and fit. Journal of the Royal Statistical Society Series B 64:583-639.

Stebbins, R.C. 2003. Western reptiles and amphibians. 3rd edition. Houghton Mifflin, New York, NY.

Stewart, D.R., A.W. Walters, and F.J. Rahel. 2016. Landscape-scale determinants of native and nonnative Great Plains fish distributions. Diversity and Distributions 22:225-238.

Stringham, R.B. 2010. Greater Sage-Grouse response to sagebrush reduction treatments in Rich County, Utah. Master's thesis, Utah State University, Logan, UT.

[USFWS] United States Fish and Wildlife Service. 2013. Greater Sage-Grouse (Centrocercus urophasianus) conservation objectives: final report. U.S. Fish and Wildlife Service, Denver, CO.

[USFWS] United States Fish and Wildlife Service. 2015. Technical reference on using surrogate species for landscape conservation. U.S. Fish and Wildlife Service, Washington, DC.

Watson, D.M., AND M.J. Watson. 2015. Wildlife restoration: mainstreaming translocations to keep common species common. Biological Conservation 191: 830-838.

Wheeler, G.C., AND J. Wheeler. 1988. A checklist of the ants of Wyoming (Hymenoptera: Formicidae). Insecta Mundi 2:231-239.

WiEns, J.A. 1989. Spatial scaling in ecology. Functional Ecology 3:385-397.

WILCOX, B.A. 1984. In situ conservation of genetic resources: determinants of minimum area requirements. Pages 639-647 in J.A. McNeely and K.R. Miller, editors, National parks, conservation, and development: proceedings of the World Congress on National Parks. Smithsonian Institution Press, Washington, DC.

WiLSON, E.O. 1987. The little things that run the world (the importance of conservation of invertebrates). Conservation Biology 1:344-346.

Wyoming Game and Fish Department. 2010. State wildlife action plan. Wyoming Game and Fish Department, Cheyenne, WY.

Zuur, A.F., E.N. Ieno, N.J. Walker, A.A. Saveliev, And G.M. Sмith. 2009. Mixed effects models and extensions in ecology with R. Springer Science \& Business Media, New York, NY.

Received 3 August 2016

Accepted 27 September 2017

Published online 16 January 2018 